\title{
A confident call to faith: Rediscovering the relevance of Christian catechisms
}

\begin{abstract}
Author:
Raymond Potgieter ${ }^{1}$

Affiliation:

${ }^{1}$ Faculty of Theology, North-

West University, South Africa

Correspondence to:

Raymond Potgieter

Email:

ray@csmdist.com

Postal address:

PO Box 19491, Noordbrug

2522, South Africa

Dates:

Received: 24 Jan. 2013

Accepted: 02 Sept. 2013

Published: 15 Nov. 2013

How to cite this article:

Potgieter, R., 2013, 'A

confident call to faith:

Rediscovering the relevance of Christian catechisms',

In die Skriflig/In Luce Verbi

47(2), Art. \#686, 10 pages.

http://dx.doi.org/10.4102/

ids.v47i2.686
\end{abstract}

\section{Copyright:}

(C) 2013. The Authors.

Licensee: AOSIS

OpenJournals. This work

is licensed under the

Creative Commons

Attribution License.
Read online:

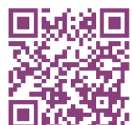

Scan this QR code with your smart phone or mobile device to read online.
Protestant heritage is synonymous with the traditional employment of catechisms and catechetical teaching of both young and old. Many denominations have shifted from this historical approach, not least because of the challenges of so-called catechetical vacuums when facing third-millennial issues. The Heidelberg, Anglican and Westminster Catechisms allow for express distinctions peculiar to each unique Protestant faith constituency, but serve acceptably within the wider ecumenical tradition. A rediscovery of the historical contexts of these historical formulations will illustrate traditional denominational Protestant flexibility accompanying its Christian creedal fixity. This study will refer to confessional content in the main without resorting to particular content. The intention is to show how these polarities could dynamically serve the confessing church in meeting present-day challenges to the Christian faith in a manner that once again will inspire confidence in its catholic witness in the third millennium.

'n Oortuigde oproep tot geloof: Die herontdekking van die relevansie van Christelike kategismusse. Die protestantse erfenis is sinoniem met die tradisionele gebruik van die kategismusse en die kategetiese onderrig van oud en jonk. Baie kerkgenootskappe neig weg van hierdie historiese benadering hoofsaaklik as gevolg van die uitdagings van die sogenaamde kategetiese leemtes in die hantering van derde millenniumkwessies. Die Heidelbergse, Anglikaanse en Westminsterse Kategismusse laat ruimte vir spesifieke onderskeidings wat eie is aan elke unieke protestantse geloofsgemeenskap, maar wat nogtans binne die breër ekumeniese tradisie aanvaar word. 'n Herontdekking van die historiese konteks van hierdie tradisionele formulerings sal tradisioneel kerklik-protestantse buigsaamheid illustreer wat met konfessionele vastheid gepaard gaan. Hierdie artikel verwys na konfessionele inhoud oor die algemeen sonder om spesifieke inhoud aan te toon. Die doel is dus om aan te toon hoedanig hierdie polariteite die belydende kerk daadwerklik kan help om die daaglikse uitdagings van die Christelike geloof op so 'n wyse te hanteer dat daar weer vertroue in die algemene getuienis van die kerk in die derde millennium sal wees.

\section{Introduction}

The Christian church claims to be the guardian of revealed truth as contained in the Bible. Historically, this translated into formulating creeds, confessions and catechisms. Creeds take on the form of 'a concise, formal, and authorised statement of important points of Christian doctrine' (Cross \& Livingstone 1974:358), for example the Apostle's and the Athanasian creeds. More specifically, a confession is 'a declaration of religious belief'. This word has also been applied to the traditional ecumenical creeds of the church. A development during the Protestant Reformation of the 16th and 17th centuries was confessional expressions of faith with the added element of defining its particular confessors communally as a distinct religious body (Cross \& Livingstone ibid:329-330). With the concern for truth in the light of differing opinions and opposition to heresy, the cure of souls, recourse was made to yet another expression of the Christian faith. Underlying this concern for truth is 'the study and dissemination of the Bible' (Bray 1994:17) which was essential to the rise of the Reformation. Its formulated truths were often expressed in the distinctly peculiar form of a catechism.

There is no manifesto available on the use of catechisms within the Christian community. A rewarding exercise though is to draw together some of the bits and pieces relevant to the subject as documented in various historical documents. These will reveal the careful boundaries delineated for individual catechisms from their historical context, purpose and distinct form. To that end selected documentation about the Heidelberg Catechism (HC), Anglican Prayer Book Catechism (APBC) and the Westminster Catechisms (WC) will be examined.

Emerging from the aforementioned will be the observation that, although these three catechisms focus on developing systematic theological distinctives, natural revelation is not particularly 
addressed as a form of revelation. This is evident from the truths disseminated from, for instance physical science and one of the reasons Christians are so divided on these matters. The church needs to express a holistic view of revelation which will uniquely define and succinctly address matters pertaining to science and theology. To that end the church may once again recapture the significant value of its catechisms for the Christian church in the 3rd millennium.

\section{Some introductory comments}

Catechism comes from kateleo and means 'to cause to listen', implying instruction. From the Latin catechismus the further implication is that of word of mouth teaching. Turrel (2006:500-508) defines a catechism as 'a manual of Christian doctrine, designed for a popular audience'. Martin Luther (1872:124, para. CCLXV) said 'The catechism must govern the church, and remain lord and ruler.' The word catechism was popularly used in the early 16th century, although the form of catechetical teaching predates that (Cross \& Livingstone 1974:249).

Catechism was originally intended as an oral means of religious instruction preparing catechumens including children and adults for confirmation of their Christian faith, for example The Book of Common Prayer (BCP) (n.d.:288-289). Preparation included teaching as well as transformation in its addressing of morals, religious practice and such matters. Finally, however, no catechism covers all the particulars of the understanding of Christian theology and, by virtue of its brevity, touches upon the essentials for Christian faith and living (Turrel 2006:500) as generically defined by the church. Little account is taken of the impact of life beyond the confines of its definition such as the historical progress of scientific discoveries and its interpretations of reality.

An example of Early Church catechetical practice was that expressed by the 'golden mouthed' John Chrysostom (c. 347-407). He, famously, viewed marriage and the family as a 'little church' which Johnson (2002) argues in a thesis includes not only responsibility of managing the church, but also of parents in teaching their children. Hippolytus of Rome (d. 235) was apparently less concerned about the size of his congregation than about the morals and values professed by its members (Harmless 1990:70). Anyone who professed some Christian conversion, but did not seek to break with a previous way of life and accept Christian practice, was summarily rejected from becoming a catechumen. According to Harmless (ibid:668), Augustine (354-430) was particularly concerned about the need to catechise the church, because 'addiction to the world' negatively impacted upon society (Harmless ibid:668-689).

Historically, instruction of neophytes and children of believers took the form of dealing with a set of searching questions followed by answers (Turrel 2006:500). Although not a new concept at the time of the Reformation, it became a standard for religious instruction.

\section{Medieval catechetical teaching}

Contextually the 16th century Reformation emerged from the background of the Middle Ages, a period Lane (2007:90) says Protestants need to revisit for its struggle between faith and reason, a contemporary problem. Whereas monastic theology tended towards a particular way of living, for example Regula Benedicti, its purpose was to elicit edification and worship and was not primarily a pursuit of knowledge for its own sake (Lane ibid:88) - a paradigm challenged during the Reformation, but not resolved.

Aristotelian logic influenced medieval theology. During this time embryonic universities emerged as the weight of scholarship gradually shifted from monastery to cathedral with persons such as Peter Abelard (1079-1142) and John Hus (c. 1369-415) who began scrutinising the church's doctrine and methodology. 'Reason had entered theology not [yet] as a means of defining Christian doctrine [which was based on revelation], but as a technique for defending and further understanding this faith' (Lane 2007:89). The Bible became available to laity in the vernacular viz. John Wycliffe (c. 1320-1384), whilst internationally this period had to deal with the fall of Constantinople in 1453, papal rivalry and the beginnings of social emergence from serfdom. By the 15th century theology was dually centred in the realm of God's revelation and philosophy (Lane ibid:89). How would the Reformation respond?

Amidst these aforementioned dynamics, medieval catechetical teaching continued to follow the Early Church's rigorous preparation of candidates for baptism with its concern for backsliding from the faith. Religious instruction prior to the Reformation generally found its place after baptism or before, for those catechumens not baptised as infants. Ascendancy of the practice of god-parenting led to sharing in the responsibility for nurturing a godchild in the content of the faith and to ensure pursuit of a moral life.

Catechetical teaching generally followed the threefold pattern of faith (Apostle's Creed), hope (Lord's Prayer) and charity (Ten Commandments). Teaching content tended towards stylistic harmony centred in sevens so that the Lord's Prayer was for instance divided into as many petitions (Cross \& Livingstone 1974:249). The Reformation, on the other hand, brought about a concern for biblical content of its catechisms to ensure expression of its doctrines.

Whilst confessions of faith express the creedal doctrines of the catholic faith and denominational distinctives, catechisms disseminate these doctrines as a form of dialogue into basic questions and answers. Traditionally, many of the questions and answers became embedded in the consciousness of the catechists to serve as standard answers to their faith. Initially catechisms served both sides of the baptismal dividing line: those who were baptised into the church as infants and those who had not yet been baptised. 


\section{History and the emergence of some catechisms}

Prior to the Reformation there was one accepted faith in Europe. Though subject to criticism, it was doctrinally dictated by Rome (Cross \& Livingstone 1974:1165). As the Protestant Reformation gained in ascendency its doctrines inevitably birthed new confessions of faith.

Confession, as a term on the European continent in the 16th and 17 th centuries, did not particularly distinguish between catechism or creed, but embraced them without particular distinction (Cross \& Livingstone 1974:329). Nevertheless, catechisms as teaching tools came about to express the rise of a new orthodoxy which of course did not go unchallenged (Lane 2007:149). Written for lay instruction they unified the masses into for instance a Lutheran expression of theology on the one hand or a peculiar Anglican theology on the other. In time this development gave rise to separate Lutheran and Anglican identities. Denominations claimed certain confessions and catechisms, whilst excluding others so that these writs often became denominationally associated. Each group claimed that its preferred doctrines most clearly expressed their distinctives in the most biblical fashion possible.

Catechetical teaching was reinforced by a dialogue in the form of question and answer. The questions and answers of for instance the $\mathrm{HC}$, reflect a truly catholic exposition of the reformed faith. Indeed, many who may remember little of a catechism may yet be able to state its first question. This question is generally developed throughout the catechism. Ursinus (1888:17) holds that ' $[t]$ he question of comfort is placed, and treated first, because it embodies the design and substance of the catechism'. Between 1530 and 1740 about 680 different questions can be identified from catechisms on the continent and in England alone (Green 1996:51). Catechisms do not necessarily follow a dialogue or question and answer format and may include more polemical approaches of confrontation (Green ibid:56-57).

Traditionally, Protestant reformed instruction is given by a catechist who may be a minister, curate, lay person or a person in good standing in the church. Catechumens were generally children, but could also be older persons. Sometimes catechetical instruction was periodically presented in church services to include the congregation as a whole. The audience was variously identified: 'all sorts of people', 'all Christians', 'all those that seek to enter the path-way of salvation', 'babes in Christ', 'babes in knowledge' and so on (Green 1996:74).

The large number and extent of catechisms and of the manner in which catechists borrow from one another is a question addressed by Green (1996) for the period 1530 1740. He distinguishes between the ideal and reality of what took place (Green ibid:4), and the impact of changing mediums such as new forms of music, visual aids, symbols et cetera - all of which affected instruction. Ideally, the idea was not just to repeat a catechism by rote, but to progress in understanding and knowledge (Green ibid:562). Moreover, in the 16th century the concern was to distinguish between the teaching of Rome and Protestant truth (Green ibid:40). From the 1640s the emphasis shifted to distinguishing the various Protestant doctrines. Christians' doctrines were generally stated in an irenic fashion in an attempt to avoid unnecessary division. A comparison of different catechisms illustrates the many points of similarity and shared doctrinal persuasions (Green ibid:91-92).

Some of the well-known catechisms of the era were Luther's Little Catechism (1529), the HC (1563), the Prayer Book Catechism (PBC) (1536, enlarged 1604, revised 1661, final form 1662), and the Westminster Shorter Catechism (WSC) (1647). Many of these catechisms became missionary standards and accompanied the process of colonisation, leading to them being translated in many foreign languages and standards for revised catechisms. Wherever these catechisms were taken, however, they served to guide the Christian church in its witness to all nations.

To show the relevance of the catechisms for the church today, this article will briefly trace the historical backgrounds, purpose and form of the $\mathrm{HC}, \mathrm{WC}$ and $\mathrm{PBC} .{ }^{1}$ Each of these catechisms has distinctives which gave rise to its formulation and for its continued historical relevance.

\section{Some historical distinctives of the Heidelberg Catechism (1563) Distinct historical background}

Von Alpen $(1863: 5,7)$ states that its history leads into a school of wisdom and that this catechism evidences the providence of God. According to Von Alpen (ibid:5), the HC was a powerful influence 'upon the destinies of entire nations and kingdoms'. From the catechism's inception, there was this identification of the present with the historical necessitated by the need for a single catechism for the Palatinate which would supersede any other in circulation and address conflicting theological divisions. Differing opinions included those particularly related to the understanding of the presence of Jesus during the service of Holy Communion and how this was reflected in the symbols of the sacrament. This came to a head in 1559 when Lutheran Tilemannus Heshusius (1526-1588) and Deacon William Klebitz, ${ }^{2}$ a Zwinglian by persuasion (or of Calvinist persuasion according to Bente 2008:334, 343) allowed their differences to enter the public arena (Chalmers 1814:426). This took place during a service of the Lord's supper when Heshusius tried to wrench the cup from Klebitz who had been forbidden to partake of the sacrament (Bente ibid:343; Nevin 1888:xi). Attempts to reconcile them failed, and both were removed from their pulpit ministries (Von Alpen ibid:16-18). Consequently Heshusius was forbidden entrance to several cities in Germany and had a reputation for controversies with Calvinists. Elector Frederick III faced a dilemma. Although personally persuaded towards

1.To that end I do not wish to specifically deal with the particular content of each catechism. That is not the purpose of this article.

2.Hesshuss, Klebiz is the spelling used by Nevin (1888:xi). 
a Zwinglian interpretation of the Lord's Supper, he also maintained that unity may be had amongst German Protestants who held differing views of mode and doctrine (Von Alpen ibid:18) even though the reigning spirit of the university, and of the land, was already more Reformed than Lutheran' (Ursinus 1888:xi).

Heidelberg University, founded in 1386, was beholden to Rome, but in time Frederick III populated it with theologians of Protestant persuasion. At his behest, Caspar Olevianus (1536-1587), former lecturer at the university and at that stage court preacher, prepared an exposition of the covenant of grace and framed it in the form of a prototype catechism (Von Alpen 1863:22-23). Zachariah Ursinus (1534-1583), lecturer at the university and known for his concise expression and clear thinking, on the other hand, cast the theological net wide to include those new and mature in faith adults and children (Nevin 1888:14-15). To that end he prepared a dual catechism (Von Alpen ibid:23). There is evidence that the catechism was, to a certain degree, the result of a team project (Bierma et al 2005:53ff., 67). After scrutiny by theologians at the university, Frederick III deemed the catechism ready for scrutiny by pastors and others throughout the Palatinate and convened a Synod at Heidelberg (1562). The clarity of its statements and faithfulness to scripture expressing the reformed faith evoked admiration and agreement. By January 19, 1563 it was decided to get it printed and distributed for use in the vernacular and in Latin. John Mayer printed the catechism in 1563 in Heidelberg which included the Elector's preface. Historically the catechism in the German language was regarded as the authentic edition for its precision in statement and verbal elegance (Von Alpen ibid:24-25). It was widely accepted within the Palatinate and reformers everywhere, but not where Protestants holding to a strong Lutheran position were in the majority. At the Diet of Augsburg (1566), Frederick III defended the HC as a true expression of the Christian faith. He answered accusations of Calvinistic partisanship stating that he had never read any of the works of John Calvin except for the commentary on Jeremiah, dedicated to him. He was thus not influenced by that in his statement (Good 1887:211). Despite opposition the catechism was, nevertheless, translated into Dutch (1564), English and Hungarian (1567), French (1570), Gaelic (1571), Hebrew (1580) and Greek (1597) to eventually circle the globe, accompanying missionaries everywhere.

\section{Historical purpose for the catechism}

Although the purpose of the church is not solely to interpret Scripture, it is of necessity dependent upon it for its ecclesial practice and so seeks clear teaching. From the first there was the identification of the need for a summary course of religious instruction of the Christian faith (Von Alpen 1863:21). Frederic III in his preface, after the adoption by the Synod of Heidelberg (January 19, 1563) and reprinted in the early catechisms, stated amongst other some of the reasons for implementing the catechism:

[That] in order not only that the youth in churches and schools may be piously instructed in such Christian doctrine and be thoroughly trained therein, but also that the Pastors and Schoolmasters themselves may be provided with a fixed form and model, by which to regulate the instruction of youth, and not, at their option, adopt daily changes, or introduce erroneous doctrine. (Bierma et al. 2005:51)

This was to serve as a guide not only in schools, but in churches and from the pulpit so that the emphasis upon youth expanded to include persons in the pew. Frederic's concern for the youth reveals his passion for the enduring impact which godly teaching brings about:

... that if our youth in early life are earnestly instructed and educated in the word of God, it will please Almighty God also to grant reformation of public and private morals, and temporal and eternal welfare. (Von Alpen ibid:21)

A further historical purpose of the catechism was to point out doctrinal error and provide reasons for the allegation. After the initial printing of the catechism, a subsequent version included more clarity from a Protestant perspective regarding mass (Von Alpen 1863:25-26). The following words appeared on the title page of the catechism: 'Nach dieser Regel forschet in der Schrift' [According to this rule search the Scriptures] (Rupp 1895:10). Instead of implying a finality it rather served as an invitation to continue reflecting upon the Bible as the source of its doctrinal statements (Rupp ibid:10). ${ }^{3}$ The fixity of faith (justification) is for instance strongly put by the $\mathrm{HC}$ Lord's Day 24, question 64 'for it is impossible that those, who are implanted into faith, should not bring forth fruits of thankfulness' (Ursinus 1888:335). It was soon recognised as having masterfully dealt with divisive doctrines. This ensured that the catechism had to be read as a whole without isolating a single doctrine. ${ }^{4}$

In due course the catechism soon affected all education within the Palatinate, whether in the home, schools, university or seminary. It was in fact enhanced when Ursinus began developing the catechism in his lectures which he did annually until 1577 . His students compiled these lectures and published it under his name. Later editions expressed the author's intentions more clearly (Ursinus 1988). The catechism served as a platform for unified teaching of the church for the present generation and for those to come (Finlayson 2005a:12-13, part 1).

\section{Brief reference to its distinctive form}

The 1563 edition did not resemble the later forms of the catechism, nor did it betray whose work was whose. Its unity was rather wonderfully organic; a joint production of its main authors together (Good 1887-177) with input from others. Formerly known as the Catechism of the Palatinate (Von Alpen 1863:11), it did not at first adopt the question and answer format and there was a lack of numbering. Therefore, statements sometimes gave the impression of being

3.This goes hand in hand with a settled conviction that the Holy Spirit in fulfilment of Christ's promise (Jn 16:13) will continually guide the church and affirm its quest for truth. 4.Von Alpen (1863) refers in this regard to the interpretation adopted regarding the
controversy which sometimes arises from considering 'Christ' and 'the whole world' controversy which sometimes arises from considering 'Christ' and 'the whole world'
an issue for the 'four point Calvinists' example. Richard Baxter and the Arminian remonstrance addressed it at the provincial Convention of The Hague, 1611. 
indiscriminate. When the second print followed, already some doctrinal changes were evident (Von Alpen ibid:25). In the first edition of 1563 the familiar format of Lord's Days was missing and only added in a later print of the same in the same year which included a more ordered format for scriptural references and precursor of its apologetic stand. ${ }^{5}$ This was Calvinism moderately stated (Good 1887:178).

'What is your only comfort in life and death? That I, with body and soul, both in life and in death, am not my own, but belong to my faithful Saviour Jesus Christ' is the first question and answer of the HC to be expounded (Ursinus 1888:17-20). Here ' $t$ t $]$ he very pith and marrow of the whole Christian religion is nowhere presented, either in ancient or modern times, in words so few and yet so weighty' (Von Alpen 1863:28). Not surprisingly this catechism was regarded as having surpassed Calvin's catechism for its sheer compass of comprehension and economic expression of cardinal Christian doctrines.

From Sunday 1 the catechism develops along the division of the epistle to the Romans (Ursinus 1888:23ff.). The first section addresses sin and its consequences; the second redemption; and the third response to God for such a great salvation. Its tone is didactic and at once confessional, expressing the grandeur of God, faith leading to worship. It develops expositionally through the Apostle's Creed, the Law and the Lord's Prayer to impress a confessional tone. The Protestant understanding of salvation rooted in God's grace underlies its confession. Consequently, the HC has been used to prepare persons for confirmation of their faith in Christ and membership of the church.

Accusations that the HC was Melachthonian or Low Lutheran were finally put to rest when the Synod of Dort in 1619 unanimously voted in favour for its acceptance as a true reflection of the orthodox faith (Good 1887:179; Schaff 2007:549). Some of the supposed intentional silences of the HC such as predestination, reprobation, covenant and sacraments were supplemented by its pronouncements (Bierma et al. 2005:94ff.).

\section{Historical distinctives of the Westminster Shorter Catechism (1647) \\ Distinct historical background}

In the attempt to capitalise on the victory of Parliament over Charles I (1600-1649) and to a lesser extent Archbishop William Laud (1573-1645), the English and Scottish Protestants convened the Westminster Assembly meeting regularly from 1643 to 1649 . This was also due to the agreement of the Solemn League and Covenant, a treaty that assured reformed religion in Scotland, England and Ireland and the reformation of present religion (Cross \& Livingstone 1974:1287). This Assembly issued the Westminster Standards

5.For a copy of the textus receptus in English of the final 1563 version, refer to Thelwall (1850:51). to include the Confession of Faith and the Larger Catechisms (LC) and Shorter Catechisms (SC) (Lane 2007:205). Although sanctioned by the Commons, it was not sanctioned by the Lords. Nevertheless, it soon found popular acceptance. The SC soon outstripping the Larger in sales (Green 1996:81) and popularity. It served subsequently as basis for many reformed denominations with changes to accommodate particular and denominational interpretations (Green ibid:81) such as the Baptist Catechism 1689.

\section{Historical purpose for the catechism}

The Calvinism expressed in the Westminster Confession was Puritan and stricter than the moderate views of the 39 Articles (Lane 2007:205). Green (1996:90) speaks of 'the hard-line Calvinism of the Westminster Catechisms', and British Calvinism did not slavishly follow Calvin (Lane ibid:205). Lane (ibid:205-206) shows how its treatment of 'limited atonement' and the distinction between assurance associated with salvation distinguish it from Luther and Calvin. Nevertheless, its purpose was religious unity not only in England, but in the whole of Britain. All parties in the Assembly saw the value of sharing a unified expression of the Christian faith which led to its continued ecumenical appeal to adherents of the reformed faith. After revising 15 of the 39 articles of the Church of England, the decision was made to frame an independent confession (Mitchell 1884:136-137). The BCP was also regarded as inadequate and doctrinally suspect (Hetherington 1890:304-305). A break had to be made. A brief catechism was deemed necessary as it would by its very nature have to express its doctrines succinctly but broadly to be inclusive of various reformed traditions. Remarkably, not one of the commissions which completed the catechisms anticipated their impact at that stage and later (Mitchell ibid:430-432). Historically these standards served as the basis of numerous confessional documents of many presbyterian and reformed churches everywhere so that some modifications to the original texts are found deviating from the critical text of 1647. A distinctive throughout the text is the inclusion of Scripture proof texts.

In spite of the the Larger Catechism (LC) being the first to be completed by the Assembly, it was never included in presbyterian hymnals as a rule. It was regarded as too verbose and so continues in the shadow of the SC and the Confession of Faith (Beveridge 1904:138). The distinct purpose of the Catechism was to effect religious unity through the express statements of doctrinal belief. However, in expressing a distinct and continued concern of the Christian church, the mandate was for ' $[a]$ catechism for the instruction of children and of the comparatively ignorant in religious truth' (Hetherington 1890:304). Historically its evangelical character allowed for its use in propagating the gospel (Hetherington ibid:380). The famous words of Thomas Carlyle, 'The older I grow - and I now stand upon the brink of eternity - the more comes back to me the first sentence in the Catechism which I learned when a child, and the fuller and deeper its meaning becomes: What is the chief end of man? To glorify God, and 
to enjoy Him for ever' (quoted in Beveridge 1904:140), reveals something of this evangelical and didactic ${ }^{6}$ spirit.

\section{Brief reference to its distinctive form}

Finlayson (2005a:12-13, part 1) points out that the context for framing the Westminster Confession and the catechisms (1648) should also take into account the development of reformed theology since the establishment of the HC (1563) and the PBC (1536; final form 1662). This contextualisation, together with puritan influence, became the defining marks of the continuing English Reformation. It was peculiar to the British Isles and distinguished it from continental confessional theology, although their respective catechisms shared the same roots of the Protestant Reformation, in particular as understood by Calvinist Protestants (Hanko 1986). The Westminster Confession and WLC and (SC) were formulated in the context of the 39 Articles of the Church of England, especially in the light of the Lambeth Articles, also known as the Nine Articles of William Whitaker (15481595) which served as an early precursor of the five points of Calvinism.

More particularly the SC was written to educate lay persons in matters of doctrine and belief in the question and answer format. This format was regarded as suitable to aid its memorisation especially by children (Finlayson 2005a:12-13, part 1). Erskine and Fisher (in Engler 1911:iii) imply that the truths expressed in the SC were already present and contained in churches and that its reception merely affirmed what was already believed. Its doctrines, together with the WCF, led to affirming and developing the presbyterian style of worship and government. Children of believers were also taught the WCF and the Bible, a practice and tradition many continued doing as adults and passed on to their children.

Although the catechism was the product of humans, 'being a form of sound words' (Erskine \& Fisher in Engler 1911:iii; cursive in the original), it faithfully represented the truths of the Bible. Engler also highlights the harmonious unity of doctrine, held to by the many formulators of the catechism and that 'divine faith is due to the words of the Holy Ghost supporting it' - a frustration to anyone promoting contrary doctrines (Erskine \& Fisher in Engler ibid:vii). Hanko (1986) is of the opinion that the SC lacks the subjective warmth of the $\mathrm{HC}$ and of some statements of the WC due to its objectivity and cold phraseology. Finlayson (2005b:12-13, part 3) agrees about the objectivity, but adds that it brought about a precision of language which allowed it to masterfully employ logic to formulate definitions and address problematic theological issues. This objectivity seems to be an appeal to reason first and then to faith. Undoubtedly the crowing jewel of the SC is its first question and answer: 'What is the chief end of man? Man's chief end it to glorify God, and to enjoy him forever ${ }^{\prime 8}$

6.The question and answer method enhanced its didactic usefulness (Cross \& Livingstone 1974:1472). The question is always partially included in the answer, reinforcing both question and answer at the same time.

7.Four versions of the catechism appeared in 1563, but with no differences between the third and fourth. This reference is to the final accepted version as textus receptus.

8.The original words of the first question in the 1647 version of the SC were: 'Question. What is the chief end of man? Answer. Mans chief end is to glorife God, an to enjoy him forever. The more modern form of spelling was merely substituted.
(Carruthers 1897:1). According to Hanko (1986), this is not sustained in the development of the catechism and does not compare to the first question and answer of the $\mathrm{HC}$ and its subsequent development: 'What is thy only comfort in life and death? That I with body and soul, both in life and death, am not my own, but belong unto my faithful Saviour Jesus Christ.'

The LC basically summarised the Westminster Confession, whilst the SC was an abridgement of the latter and for use in catechising children. It also exhibits a strong ethical persuasion most likely representative of the puritan influence (Hanko 1986). Thomas Boston (1676-1732) (1993:9) suggested that the doctrines are merely illustrative of the Christian religion, implying there is much more to be found upon earnest study. For his own day he viewed this study as a necessity so that in facing times of trial Christians may not to lapse into apostasy.

The SC, unlike the LC, does not define the church or its officers, nor does it cover the creeds. Mitchell (1884:430) says that as far as possible the committee attempted to remove anything related to organisation of Christians. Whatever was regarded as treating external community was regarded as non-essential and superfluous. The impression is that their efforts were to primarily preserve the essence of the faith centred upon the Gospel and in which all Protestant youth could unite (Mitchell ibid:430-431). It was done with the dictum in mind of what the youth needed to hear and not what they thought they had (Mitchell ibid:435).

\section{Some historical distinctives of the Book of Common Prayer: Anglican Catechism (1536; final form 1662) Distinct historical background}

'Anglican' stems from ecclesia anglicana or 'English church' from the Middle Ages, reflecting Christian presence in Britain and Ireland long before the missionary efforts of St. Augustine (597) sent from Rome (Cross \& Livingstone 1974:58, 1043). Through the initial work of John Wycliffe (c. 1330-1384) and later of William Tyndale (1494-1536) the Bible became available in the vernacular and the telling influence for the later English Reformation (Bray 1994:17-18) continued in the authorised version of 1611. Biblical preaching, writings and pamphlets in circulation contributed to the fact that by the 16th century its ground in England had been laid. Luther's works, entered into England, were translated and received with eagerness, although the Roman Catholic Church vehemently opposed their distribution at peril. Gospel matters were the centre of discussion at the University of Cambridge and to a lesser extent at Oxford University. The annulment of Henry VIII's marriage with Catherine of Aragon also signalled the rift of the Christian church in England from Rome. This led to the concept of ecclesial independence of the realm and a transfer of power from pope to king, bringing about the necessity to enunciate the Christian faith peculiar to the Anglican communion. 
Martin Bucer (1491-1551), who had laboured energetically for the reformation on the continent (Von Alpen 1863:13), continued his work in England. Thomas Cranmer (14891556), later Archbishop of Canterbury, who was influenced by Bucer as John Calvin was before him, saw theological reform as a concern for the purity of doctrine and pastoral care and some measure of discipline (Lane 2007:172). Cranmer was significantly influential in developing the 1549 and 1552 prayer books (Lane ibid:172). His 42 Articles of Religion of 1553 were eventually refined to 39 which became the official doctrinal statement of the Church of England in 1571 and was included in the BCP (Bray 1994:284). Though the Articles held to Protestant theology, with leanings towards Calvinism (Bray ibid:284), a characteristic of the $\mathrm{BCP}$ and its catechism is its broad open-ended doctrinal statements. This was due to Bucer persistently seeking a way to reconcile the different groups (Protestants, Roman Catholic, Zwinglians, Anabaptists, Lutherans) comprising the Christian community (Lane ibid:172-173).

An irreducible compilation of sources for the Christian faith in England was formulated as early as 1281 (Duffy 2005:53). This comprised of the Creed, Ten Commandments, New Commandment, seven works of mercy, virtues, vices and sacraments. Although ecclesial rather than scriptural, authority and interpretation held sway at the time a new learning ${ }^{9}$ founded on scepticism was emerging (Innes 1900:3), developing into what Innes terms the scholars movement, 1496-1529' (Innes 1900:12ff.). Duffy (2005:87) also traces how the catechetical teaching adapted to changing circumstances in England. Often the initiative was taken by lay persons concerned for the lay masses. In this tradition, Cranmer, leading by example, initially took the path of abolition instead of reform (Duffy ibid:380). This was evident in the advent of the BCP which signified a radical break from Rome as it discontinued the Romish cycle of feasts. It also broke with sacramental formularies (Duffy ibid:464-465, 472) introducing emergent doctrinal views allowing for royal supremacy (Duffy ibid:381).

\section{Historical purpose of the Prayer Book Catechism}

By virtue of its inclusion in the BCP the Anglican Catechism must be understood in that context. It cannot be totally divorced from the views opined in the prayer book which sought to bring about a practice that would serve as a middle way between various reformed expressions of the Protestant faith and provide sufficient latitude to leave it openended (Green 1996:20). Jeanes (2006:20) opines that, whilst Cranmer's prayer book language could imply much, at the same time it could be sufficiently vague to serve as a bridge spanning cultural divides for unity in prayer and worship. At the same time, however, it must be recognised that it also disguised his radical protestant theology (Jeanes ibid:28).

In this way it also sought to bridge the gap between Roman Catholicism and Protestant faith in reformational fashion. The catechism espoused a broad sweep of reformed 9.See the early influence of this new learning in England (Carter 1912:9-17). theology without reference to particular scriptures to avoid unnecessary interpretative controversy. Green (1996:73f.) suggests that its expositors went to some length to give an account of its teaching through separately developing alternate catechisms or interpretations (cf. Allen 1892). Some alternate catechisms were specifically aimed at children, the youth and the unconverted, and others at scholars. A mark of the PBC is that it does not generally include scriptural references to substantiate its statements. Nevertheless the catechist, usually the curate of the parish, was to be knowledgeable in theological matters and follow the question and answer method (Allen ibid:5-6). Unfortunately, as Allen (ibid:7, 12) points out, the opinion is that it was more of an emphasis upon correct answers than affirming a living faith of the heart.

The catechism distinguishes between baptismal vows and its affirmation. Traditionally, the Apostle's Creed was accepted as the basis for its baptismal faith, and the Nicene Creed as the sufficient, though not full statement of the Christian faith. A continuing episcopal government necessitated that the bishops, upon confirming a candidate in the Christian faith, should be satisfied that such person had been truly and sufficiently examined to give a reason for the faith as espoused by the PBC (Allen 1892:2). Continuation within the faith in the Anglican tradition also ensured its continued reinforcement by the set liturgy of the Prayer Book.

\section{Brief reference to its distinctive form}

Because some form and structure of its catechism was always part of the whole BCP of the Church of England, the denomination always had a close association with teaching, liturgy and worship. Its inclusion, according to Turrel (2006:501), was due to its preparatory role to the ritualised activity of the service of confirmation. The BCPs of 1536, 1538 and 1547 included the Apostle's Creed, Lord's Prayer and the Decalogue (Turrel ibid:501). As these were regarded as fundamental to religious instruction it was expected that all members of the denomination would at some stage memorise them.

Price and Weil (2000:75) point out that from the beginning the church's bishops expressed spiritual concern for the connection between faith and its normative expression in godly living. This is clear from the format of the confirmation service and first question of the catechism. A baptised candidate first professes his or her baptism in public and to the bishop. This is followed by a clear statement of the principal matters pertaining to Christian faith (Apostle's creed, Ten Commandments, Lord's Prayer and the sacraments) into which the candidate had been baptised. The catechism famously states its first question: 'What is your name? Answer: $\mathrm{N}$ or $\mathrm{M}^{\prime}$, emphasising a transition towards personal affirmation and accountability in the confession of faith. This format first associated the catechism with the service of confirmation in the BCP of 1549. Upon confirmation, the 
confirmands usually partook of their first holy communion. The catechism was periodically expanded upon until its final refinement in the BCP (1662). Significantly it was not only now associated with confirmation of a candidate's faith, but its insertion was immediately after that of the ministration of baptism and preceded the service of confirmation.

The BCP refers doctrinally to various creeds. For instance, the Nicene Creed forms part of the service of Holy Communion. The Athanasian Creed may be substituted for the Apostle's Creed on certain feast days such as Christmas, Easter day and so on. Clearly the doctrinal form of the Christian faith, expressed by the moderate Calvinism of the 39 Articles, is liturgically reiterated in the context of liturgical worship. This extends and affirms catechetical instruction as a lifelong experience in the Church of England in the context of worship. No other Anglican catechism developed in former British colonies has ever superseded it (Turrel 2006:501). This is a testimony to Bucer's conciliatory legacy. It does not mean that all who appreciate the $\mathrm{PBC}$ is unanimous regarding its theology. Courtenay (1964:367, 380), for instance, accuses Cranmer of traditional 'nomilanism' as opposed to McGee's (1966:192-196) $)^{10}$ counter-claims.

Changes to the BCP have traditionally been met with strong opposition, not because of its cultus, but because of whether doctrinal changes would move the church towards Rome (Buchanan 2006:263). Such a move would have far-reaching effects necessitating doctrinal changes to the $\mathrm{BCP}$ and its catechism and articles.

\section{Issues to be faced in the 3rd millennium}

A number of 'in your face issues' confront the Christian church worldwide, some more obvious and others less so. Whilst general principles may suffice for broad sweeping statements, 3rd millennial issues tend to demand a specific address. To name a few:

Within the Christian communion the perception of the Word of God as unchanging and sufficient for faith is under immense fire. New translations of the Bible brought questions about the assumption whether God may be properly known in any language at all, let alone one. Amongst evangelicals this led to formulating the Chicago Statement on Biblical Inerrancy of 1978 which is not only reminiscent of the Vatican's Dei Verbum, but according to Geisler and Roach (2011), an especial need to establish inerrancy for a 'new generation'. Such statements polarise the Christian community in its approach to science, a playoff between literal translation and organic translations of for instance the creation accounts of the Bible, both maintaining its authority.

International cultural interpretations of fellowship amongst Christians who may be historically or politically

10.These articles reflect the 1964 debate between McGee and Courtenay at variance with one another redefined, accepted European understandings of the mode of Christian contact (Buchanan 2006:261-270; Rahner 1973). The BCP 1662 has been criticised as being 'logocentric, heavily clericalist and male-oriented' which favours the Anglican communion's hierarchical organisation (Mombo 2006:277-286), thus impacting upon the catechism and its relevance for all genders. Nor is the pedagogical element of catechetical teaching emphasised as it once was with the emergence of so many alternate curriculums for Sunday school and young people going beyond the oral medium. These distinctions of cultural ecclesial dynamics need biblical answers if they are to be addressed instead of simply accommodated. A catechism may be regarded as one of the many tools available to the church to lead a person deeper into the Word of God. This deepening may be manifested in various ways. See the following examples.

The emergence of evangelists in the 19th and 20th centuries brought about a questioning of matters enshrined in the catechisms such as paedo baptism (LeMarquand 2006:287-297). The questionable independence of evangelists and their 'back to the Bible call' caused many sincere believers to bypass the catechisms in for instance requests for rebaptism, an independence in Bible teaching based upon the individual preacher's view of the Bible, whether it conformed to accept confessional teaching of the catechisms or not. At its 1998 Synod the Christian Reformed Church added a footnote to question and answer 80 of the $\mathrm{HC}$ as no longer representing Rome's teaching about the mass today (DeYoung 2010:250, fn. 33). On the other hand, whilst question and answer 87 do not specifically refer to homosexuality, it would not be inappropriate to consider an insertion of words such as 'homosexual perversion' (DeYoung ibid:239-247; cf. 247), as they would not violate the spirit of its author (Ursinus) or content. The 'Brief Statement of Faith' (1991) ${ }^{11}$ emphasises in its preface the one catholic faith that truth cannot be found in one person, church or tradition alone. New light from God's Word may be gleaned together with other churches too (Placher \& Willis-Watkins 1992:10-11). Another example of the spirit of change is manifested in the PBC adapted to the changing face of South African society is that of Ian Carrick (1997:v) of the Church of the Province of Southern Africa's APBC (1989). Underlying his changes is Carrick's view (ibid:iii) of creation on a journey of continual change. However, these more obvious examples are not the only struggles encountered.

Some more subtle challenges are, however, in the offing. The encompassing view of the world hundreds of years ago does not equate with that of the third millennium. Kraus (2006:541-544), for instance, wrestles with relating the BCP with technology, and Morris (2006:545-550) with cyberspace. Science and technology need to be addressed by the church, but how about addressing its relationship with sport to its iconic heroes and their heroism and the 'sacred moments' 11.Adopted by the Presbyterian Church (USA) as part of its Book of Confessions. 
(Dreyfus \& Kelly 2011:193-194f.) of presence $^{12}$ in an attempt to find some meaning to it? ${ }^{13}$ These matters are part of the conversation of the community of believers as well as outside of it.

However, the doctrinal net goes wider. Augustine's 'addiction to the world' may express itself differently today. In 1972 the Church of Rome initiated the Rite of Christian Initiation for Adults to facilitate the process of reform to accommodate persons on a spiritual journey expressing some interest in Jesus Christ (Harmless 1990:1, 2). If such divisions are acceptable to some Christian communities, its reasons must define the church's thinking in similar present and future matters to distinguish between pastoral and scriptural toleration.

In South Africa's apartheid struggle the divided church emerged as the dual conscience of the nation. Christians in both camps resorted to the Bible. Some found solidarity in a form of liberation theology, whilst others sought to justify segregation. Whilst the catechisms do ask questions, the question before us is: Does it also ask questions relevant to for instance the youth of South Africa, questionable acceptance of and violent behaviour towards the gay community, the growing numbers of divorced persons and single parents? Nobody expects all the questions to be addressed, but surely some of them deserve to be.

Without a doubt a serious challenge to the Christian faith is the New Atheism, a stand against all forms of religion levelled by persons such Richard Dawkins, Daniel Dennet, Chris Hitchens and Sam Harris. Older atheism denuded Christianity from the supernatural, but acceded to the existence of a watered down religion and God hypothesis (Mohler 2008). Plantinga and McGrath, in their rebuttals, do a fine job of answering this onslaught. Finally, however, for many evangelical Christians, their arguments betray weakness in that both accept evolution as a process (Mohler ibid:84). Their arguments can be turned on themselves by the aforementioned Horsemen of the Apocalypse, demanding that they too accept the logical conclusions of evolution (Mohler ibid:84-85). As Lane (2007:90, 234) intimated, the Reformation needs to be revisited through the Middle Ages. In this period the church wrestled with faith and reason, an unresolved issue which continued into the 3rd millennium (Lane ibid:234-235). The point here is that the answers are not primarily a referral to the catechisms; essentially it boils down to being a matter of revelation and not a devaluation of any catechism.

\section{Concluding with a way forward}

The continued influence of the $\mathrm{HC}$ and other reformed catechisms serving as maps for the Christian faith, although waning in some circles, warrants appreciation. They survived the test of time from the Reformation onwards but, in this

12.One sometimes hears references to the sacred (hallowed ground) in the mention of for instance Lord's (home of cricket) in St. John's Wood road, London, The Wanderers Club in Illovo, North Road in Johannesburg, Loftus Versfeld in Arcadia, Pretoria, particularly on the days of important matches.

13.Dreyfus and Kelly (2011) suggest that the spirit of nihilism pervading society may be reassessed in the light of great historical moments and figures suggesting that meaning may be existent and worth recapturing. writer's opinion, should rediscover some of the ecumenical elasticity which made for their unique biblical historical formulations, although widely different in some instances, each true to Scripture serving their particular constituencies. Historically both the HC and the SC became accepted beyond their constituencies, whilst the PBC's influence extended mainly to the Anglican Communion worldwide.

Reformation catechisms essentially proceeded from special revelation only. Its reasoning was founded upon proof texts, although the PBC is the exception in this regard, but not when considered in the entirety of its liturgical context. Whilst recognising the immense worth of catechisms, the Bible points to the centrality of Jesus Christ, who alone is the ultimate source of Christian faith. The worth of any creed or catechism must be seen in that light. This inward looking of catechisms reveals humankind in relation to God and his creative works. It is as such particularly meaningful for the church. However, this introspectiveness of the catechism is proving to be its Achilles heel. Historically not much attention was paid to emerging tensions of Christian living within the wider world. It was not part of the catechism conversation, and so it became a struggle for credibility. Although church authority and its claims for authenticity based upon its spiritual sources are at the low end of any spectrum, the spirit of ecumenical accommodation and faithful adherence to the scriptures remain a continual testimony of the catechisms.

Generally the catechisms serve the church today in at least three ways. Firstly, these ecumenical documents jointly and unequivocally express essential Christian faith of the Christian community. Secondly, the three catechisms still demand that their initial questions be considered and answered. Thirdly, the pastoral concerns addressed in the catechisms may be expanded upon to address the wider relation of God and the world, God and humankind, humankind and the world to bring about an authentic Christian engagement to the fullest expression of what it means to live as Christ's children in this world. To that end the HC may well be the best suited to lead the way for reasons stated above. There is no sell-by date for the truth. Simply put, the task is to make it available to the best of our abilities for each generation, to be seriously considered by the church and those outside of its fold.

This is no attempt suggesting redefinition of catechetical questions and answers; simply a call that new questions be considered to embrace God's special and general revelation to its fullest extent. From its historical ecumenical appeal and moderate theological formulations the HC is ideally suited to continue an open-ended development of thoughtful exposition and application of the Bible message to make sense and of this present world and its context within the wider universe.

\section{Acknowledgements Competing interests}

The author declares that he has no financial or personal relationship(s) which may have influenced him in writing this article. 


\section{References}

Allen, A.J.C., 1892, The church catechism. Its history and contents, Longmans, Green \& Company, London.

Bente, F., 2008, Historical introductions to the symbolical books of the evangelical Lutheran church, The Echo Library, Teddington.

Beveridge, W., 1904, A short history of the Westminster assembly, T\&T Clark, Edinburgh.

Bierma, L.D., Gunnoe, C.D. Jr., Maag, K.Y. \& Fields, P.W., 2005, An Introduction to the Heidelberg catechism: sources, history and theology: With a translation of the smaller and larger catechisms of Zacharias Ursinus, Baker Academic, Grand Rapids.

Boston, T., [1853] 1993, Commentary on the shorter catechism, Vol. 1. Classic Collector's Edition, Still Waters Revival Books, Edmonton.

Bray, G. (ed.), 1994, Documents of the English Reformation, Fortress Press, Minneapolis.

Buchanan, C., 2006, 'Preserving the classical Prayer Books', in C. Hefling \& C. Shattuck (eds.), The Oxford guide to The Book of Common Prayer: A worldwide survey, pp. 261-270, Oxford University Press, Oxford/New York.

Carrick, I., 1997, Transforming the world through Christian ministries: Training for ministries. Based upon the Anglican Prayer Book Catechism, lan Carrick, Fish Hoek.

Carruthers, W. 1897, The Shorter Catechism of the Westminster Assembly of Divines: being a facsimile of the first edition, which was ordered to be printed by the House of Commons. 25 November, 1647, Presbyterian Church of England, London.

Carter, C.S., 1912, The English church and the reformation, Longmans, Green \& Company, London. PMid:20766382

Chalmers, A., 1814, The general biographical dictionary: containing an historical and critical account of the lives and writings of the most eminent persons of every nation; particularly the British and Irish; from the earliest accounts to the present time, New edn., revised and enlarged by A. Chalmers, Vol. 17, Nichols, Son \& Bentley, London.

Courtenay, W.J., 1964, 'Cranmer as a nominalist - sed contra', Harvard Theological Review 57(04), 367-380. http://dx.doi.org/10.1017/S0017816000023348

Cross, F.L. \& Livingstone, E.A. (eds.), 1974, The Oxford dictionary of the Christian church, 2nd edn., Oxford University Press, Oxford.

DeYoung, K.L., 2010, The good news we almost forgot: rediscovering the gospel in a 16 th century catechism, Moody Publishers, Chicago.

Dreyfus, H. \& Kelly S.D., 2011, All things shining: Reading the Western classics to find meaning in a secular age, Free Press, New York.

Duffy, E., 2005, The stripping of the altars. Traditional religion in England c. 1400-c. 1580, Yale University Press, New Haven \& London.

Engler, W.M., 1911, The Westminster assembly's shorter catechism explained by way of question and answer, Part 1, Presbyterian Board of Publication and SabbathSchool Work, Philadelphia.

Finlayson, A., 2005a, 'Heidelberg and Westminster: two reformed confessions, part 1 historical background', New Horizons 26(1), 12-13, January.

Finlayson, A., 2005b, 'Heidelberg and Westminster: two reformed confessions, part 3: the Shorter Catechism', New Horizons 26(3), 12-13, March.

Geisler, N.L. \& Roach W.C., 2011, Defending inerrancy, affirming the accuracy of scripture for a new generation, Baker Book House, Grand Rapids.

Good, J.I., 1887, The origin of the reformed church in Germany in the seventeenth century, Daniel Miller, Reading.

Green, I., 1996, The Christian's ABC: Catechisms and catechizing in England c. 15301740 , Clarendon Press, Oxford.

Hanko, H., 1986, 'A comparison of the Westminster and the Reformed confessions', Protestant Reformed Theological Journal 20(1), November.

Harmless, W., 1990, 'Augustine and the catechumenate: A catechetical perspective', PhD dissertation, The Graduate School of Arts and Sciences, Boston College.
Hetherington, W.M., 1890, History of the Westminster assembly of divines, 5th edn., Anson D.F. Randolph \& Co, New York.

Innes, A.D., 1900, Cranmer and the reformation in England, Charles Scribner's sons, New York.

Jeanes, G., 2006, 'Cranmer and Common Prayer' in C. Hefling \& C. Shattuck, The Oxford guide to the Book of Common Prayer: A worldwide survey, New York, pp. 20-38, Oxford University Press, New York.

Johnson, M., 2002, 'Saint John Chrysostom's teaching of marriage as a little church, from a theological, biblical, and cultural viewpoint', MA thesis, Concordia Theological Seminary, Fort Wayne.

Kraus, D., 2006, 'The Book of Common Prayer and technology,' in C. Hefling \& C Shattuck (eds.), The Oxford guide to The Book of Common Prayer: A worldwide survey, pp. 541-544, Oxford University Press, Oxford/New York.

Lane, T., 2007, A concise history of Christian thought, T\&T Clark, London.

LeMarquand, G., 2006, 'The Anglican Church of Kenya', in C. Hefling \& C. Shattuck (eds.), The Oxford guide to The Book of Common Prayer: A worldwide survey, pp. 287-297, Oxford University Press, Oxford/New York.

Luther, M., 1872, The table talk of Martin Luther, transl. \& ed. W. Hazlitt, New edn., to which is added The life of Martin Luther by Alexander Chalmers with additions from Michelet and Audin, Bell \& Daldy, London.

McGee, E.K., 1966, 'Cranmer's nominalism reaffirmed', Harvard Theological Review 59(02), 192-196.

Mitchell, A.F., 1884, The Westminster assembly: Its history and standards, Presbyterian Board of Publication, Philadelphia.

Mohler, R.A. Jr., 2008, Atheism remix: A Christian confronts the new atheists, Crossway Books, Wheaton.

Mombo, E., 2006, 'Anglican liturgies in Eastern Africa', in C. Hefling \& C. Shattuck (eds.), The Oxford guide to The Book of Common Prayer: A worldwide survey, pp. 277-286, Oxford University Press, Oxford/New York.

Morris, C. L., 2006, 'The Prayer Book in cyberspace', in C. Hefling \& C. Shattuck (eds.), The Oxford guide to The Book of Common Prayer: A worldwide survey, pp. 545-550, Oxford University Press, Oxford/New York.

Nevin, J.W., 1888, 'Introduction', in Z. Ursinus (ed.), The commentary of dr. Zacharias Ursinus on the Heidelberg Catechism, pp. ix-xxiv transl. G.W. Williard, Elm Street Printing Company, Cincinnati.

Placher, W.C. \& Willis-Watkins, D., 1992, Belonging to God. A commentary on A Brief Statement of Faith, Wesminster/John Knox Press, Louisville.

Price C.P. \& Weil, L., 2000, Liturgy for living, rev. ed., Morehouse Publishing, Harrisburg, PA.

Rahner, K., 1973, Belief today, Sheed \& Ward, London.

Rupp, W., 1895, 'The reformed church and her creed', in Reformed Quarterly Review No. 1, Vol. XLII, pp. 1-18, Reformed Church Publication House, Philadelphia.

Schaff, P., 2007 The creeds of Christendom: history of the creeds, vol. 1, part 2, Cosimo Classics, New York.

The Book of Common Prayer n.d., Cambridge University Press, Cambridge. [BCP]

Thelwall, A.S., 1850, Heidelberg catechism of the reformed Christian religion, first published in 1563; with a preface containing historical facts and other illustrative matter, Wertheim \& Macintosh, London.

Turrel, J.F., 2006, 'Catechisms', in C. Hefling \& C. Shattuck (eds.), The Oxford guide to The Book of common prayer: A worldwide survey, pp. 500-508, Oxford University Press, New York.

Ursinus, Z., 1888, The commentary of dr. Zacharias Ursinus on the Heidelberg Catechism, transl. from the original Latin by G.W. Williard, Elm Street Printing Company, Cincinnati.

Von Alpen, H.S., 1863, The history and literature of the Heidelberg Catechism and of its introduction into the Netherlands, transl. J. F. Berg, W. S. \& A. Martien, Philadelphia. 